\title{
Adsorption of Hexavalent Chromium Using Banana Pseudostem Biochar and Its Mechanism
}

\author{
Shuang Xu, Weiguang Yu, Sen Liu, Congying Xu, Jihui Li * and Yucang Zhang * \\ Key Laboratory of Ministry of Education for Advanced Materials in Tropical Island Resources, College of \\ Materials and Chemical Engineering, Hainan University, Haikou 570228, China; Shuangxu0216@163.com (S.X.); \\ yuweiguang666@163.com (W.Y.); haidaliusen@163.com (S.L.); xucongying1229@sina.com (C.X.) \\ * Correspondence: lijihui@hainu.edu.cn (J.L.); yczhang@hainu.edu.cn (Y.Z.)
}

Received: 1 October 2018; Accepted: 14 November 2018; Published: 17 November 2018

\begin{abstract}
A low-cost biochar was prepared through slow pyrolysis of banana pseudostem biowaste at different temperatures, and characterized by surface area and porosity analysis, scanning electron microscopy (SEM), Fourier-transform infrared (FTIR) spectroscopy, and X-ray photoelectron spectroscopy (XPS). It was shown that the biochar prepared at low pyrolysis temperature was rich in oxygen-containing groups on the surface. Adsorption experiments revealed that the biochar prepared at $300{ }^{\circ} \mathrm{C}$ (BB300) was the best adsorbent for $\mathrm{Cr}(\mathrm{VI})$ with $125.44 \mathrm{mg} / \mathrm{g}$ maximum adsorption capacity at $\mathrm{pH} 2$ and $25^{\circ} \mathrm{C}$. All the adsorption processes were well described by pseudo-second-order and Langmuir models, indicating a monolayer chemiadsorption. Furthermore, it was demonstrated that adsorption of $\mathrm{Cr}(\mathrm{VI})$ was mainly attributed to reduction of $\mathrm{Cr}(\mathrm{VI})$ to $\mathrm{Cr}(\mathrm{III})$ followed by ion exchange and complexation with the biochar.
\end{abstract}

Keywords: biochar; banana pseudostem; chromium; adsorption mechanism

\section{Introduction}

Chromium, a toxic heavy metal, is widely discharged into the aquatic environment from various industries [1,2], causing serious harm to human health directly or indirectly [3-5]. Usually, chromium exists in hexavalent and trivalent forms in polluted water. Hexavalent $\mathrm{Cr}$ is highly toxic, carcinogenic and allergenic, while trivalent $\mathrm{Cr}$ is an essential trace element for mammals and less toxic $[2,6-8]$. Many treatment methods have been developed for removal of hexavalent chromium from water in the past decades, such as chemical precipitation [9], sedimentation [10], flocculation [11], adsorption [12], ultrafiltration [13], ion exchange [14], chemical coagulation [15], and so on. Being effective and operationally simple, adsorption is a useful method for removal of hexavalent chromium, solving the problems of sludge disposal [16,17].

Biochar, a cost-effective and green carbon material prepared from biomass through thermal conversion in an oxygen deficient environment $[18,19]$, has been widely used to remove or immobilize $\mathrm{Cr}(\mathrm{III})$ and $\mathrm{Cr}(\mathrm{VI})$ due to their large specific surface area, high porosity and abundant functional groups on surface $[20,21]$. As the adsorption capabilities of biochar are significantly affected by biomass types [20,21], a series of biomass including oak wood, oak bark [22], ramie [23], cotton stalk [24], beet tailing [25], coconut coir [26], leaf of Leersia hexandra Swartz [27] and so on have been employed to make biochars by pyrolysis at different temperatures for removal of hexavalent chromium in the past decades. The adsorption capability of these biochars ranged from $3.03 \mathrm{mg} / \mathrm{g}$ to $349.81 \mathrm{mg} / \mathrm{g}$, depending on the biomass feedstock. However, the application of biochars for removal of $\mathrm{Cr}(\mathrm{VI})$ was limited by either low adsorption efficiencies or less production of biomass feedstocks. For example, the adsorption capability of Leersia hexandra Swartz leaf biochar was up to $349.81 \mathrm{mg} / \mathrm{g}$, but the production of Leersia hexandra Swartz leaf was less; even oak wood was available in large quantities, 
the adsorption capability of oak wood biochar was only $3.03 \mathrm{mg} / \mathrm{g}$. As a result, biochars with high $\mathrm{Cr}(\mathrm{VI})$ adsorption capability from large-scale and low-cost biowaste are still highly necessary for remediation of $\mathrm{Cr}(\mathrm{VI})$ containing waste water.

Banana pseudostem, a major residual waste of banana which is one of most widely distributed consumed food crops, is massively generated every year [28]. Banana pseudostem consists mainly of cellulose, hemicellulose, pectin and lignin [29]. Here, banana pseudostem was used as material to prepare biochar through direct pyrolysis at different temperatures and both absorption capability and adsorption mechanism of the biochar for $\mathrm{Cr}(\mathrm{VI})$ were investigated in aqueous solution.

\section{Materials and Methods}

\subsection{Materials}

All chemicals including $\mathrm{HCl}, \mathrm{KOH}, \mathrm{H}_{2} \mathrm{SO}_{4}, \mathrm{H}_{3} \mathrm{PO}_{4}, \mathrm{CH}_{3} \mathrm{COCH}_{3}, \mathrm{C}_{13} \mathrm{H}_{14} \mathrm{~N}_{4} \mathrm{O}$ and $\mathrm{K}_{2} \mathrm{Cr}_{2} \mathrm{O}_{7}$ were analytical grade reagents and purchased from Aladdin or Macklin in Shanghai of China. A stock solution $(1000 \mathrm{mg} / \mathrm{L})$ of $\mathrm{Cr}(\mathrm{VI})$ was prepared by dissolving $\mathrm{K}_{2} \mathrm{Cr}_{2} \mathrm{O}_{7}$ in deionized water (Water treatment system, LD-UPW-20, Leading, Shanghai, China). The stock solution was then diluted to desired concentrations. The $\mathrm{pH}$ of $\mathrm{Cr}(\mathrm{VI})$ solution was adjusted by suitable concentration solution of $\mathrm{HCl}$ or $\mathrm{KOH}$.

\subsection{Preparation of Banana Pseudostem Biochars}

Banana pseudostem, the layered pseudostem wrapped in the trunk of banana trees, was supplied by the farms around Haikou City, Hainan Province, China. The sample was air-dried at $60{ }^{\circ} \mathrm{C}$ by blast drying oven and then smashed to pass through a 60 mesh sieve $(0.3 \mathrm{~mm})$. The banana pseudostem powder was heated with a rate of $5^{\circ} \mathrm{C} \mathrm{min}^{-1}$ until it reached target temperature $(200,300,400,500$, $600^{\circ} \mathrm{C}$ ) and then maintained the temperature for $1 \mathrm{~h}$ in a muffle furnace with tubular reactor under suitable nitrogen flow rate. The resulting biochars were cooled down to room temperature under nitrogen flow. Then the biochar was washed with deionized water for several times, dried at $60{ }^{\circ} \mathrm{C}$ for $24 \mathrm{~h}$. The dried biochars were stored in an airtight desiccator prior to use and were abbreviated as BB200, BB300, BB400, BB500 and BB600 respectively, according to the pyrolysis temperature.

\subsection{Characterization of Banana Pseudostem Biochars}

The textural property was analyzed using $\mathrm{N}_{2}$ sorption at $77 \mathrm{~K}$ on an ASAP 2460 surface area and porosity analyzer (Micromeritics, Norcross, GA, USA). The biochars (0.1-0.2 g) were degassed at $100{ }^{\circ} \mathrm{C}$ in vacuum before test. The surface area, pore volume and average pore size were all calculated by the Brunauer-Emmett-Teller (BET) method. The microscopic properties and surface morphologies were characterized using a S-3000N scanning electron microscope (Hitachi, Tokyo, Japan) operated at $10 \mathrm{kV}$. The surface functional groups of the biochars were characterized by Fourier-transform infrared (FTIR) spectrometer (Bruker Tensor 27, Ettlingen, Germany). The biochars were grinded with $\mathrm{KBr}$ and rolled into sheets, then recorded between 400 and $4000 \mathrm{~cm}^{-1}$. The surface elemental content $(C, O$, $\mathrm{N}$ and $\mathrm{Cr}$ ) and surface functional groups were determined by $\mathrm{X}$-ray photo-electron spectra (XPS) with an Escalab 250Xi spectrometer (Thermo Scientific, Waltham, MA, USA).

\subsection{Adsorption Experiments}

Batch adsorption experiments of $\mathrm{Cr}(\mathrm{VI})$ were performed by adding biochars $(50 \mathrm{mg})$ and aqueous $\mathrm{K}_{2} \mathrm{CrO}_{4}$ solution $(50 \mathrm{~mL})$ into $100 \mathrm{~mL}$ sealed conical flasks and shaking at $180 \mathrm{rpm}$ on a thermostat shaker for desired time. For effect of $\mathrm{pH}$ on adsorption efficiency, the adsorptions were tested at $\mathrm{pH}$ ranged from 1.0 to 5.0 using a $200 \mathrm{mg} / \mathrm{L} \mathrm{Cr}(\mathrm{VI})$ concentration. For kinetic experiments, BB300, BB400, $\mathrm{BB} 500$ and $\mathrm{BB} 600$ were mixed with $\mathrm{Cr}(\mathrm{VI})$ solution at $\mathrm{pH} 2$, respectively, then the mixtures were shaken for different time interval $(0.5,1,2,3,5,9,13,18,24,30,36,42$ and $48 \mathrm{~h})$. Adsorption isotherms were 
carried out for $48 \mathrm{~h}$ by maintaining the temperature at $25^{\circ} \mathrm{C}$ using different $\mathrm{Cr}(\mathrm{VI})$ concentrations (25, 50, 100, 200, 300, 400 and $600 \mathrm{mg} / \mathrm{L}$ ) with initial pH 2.

The $\mathrm{Cr}(\mathrm{VI})$ concentrations before and after adsorption were determined on a UV-vis spectrophotometer (MAPADA UV-3300PC, Shanghai, China) at wavelength of $540 \mathrm{~nm}$ using 1.5-diphenylcarbazide as indicator. The adsorption amount of $\mathrm{Cr}$ onto banana pseudostem biochars was calculated by the difference of concentrations before and after adsorption. The adsorption capacities of biochars towards $\mathrm{Cr}(\mathrm{VI})$ were determined as follows:

$$
\mathrm{q}_{\mathrm{e}}=\frac{\left(\mathrm{C}_{0}-\mathrm{C}_{\mathrm{e}}\right) \mathrm{V}}{\mathrm{M}}
$$

where $\mathrm{q}_{\mathrm{e}}(\mathrm{mg} / \mathrm{g})$ is the adsorption capabilities of biochars; $\mathrm{C}_{0}(\mathrm{mg} / \mathrm{L})$ and $\mathrm{C}_{\mathrm{e}}(\mathrm{mg} / \mathrm{L})$ are the $\mathrm{Cr}(\mathrm{VI})$ concentrations before and after adsorption, respectively; $\mathrm{V}(\mathrm{L})$ is the adsorbate solution volume; $\mathrm{M}(\mathrm{g})$ is the dosage of biochar.

\section{Results and Discussion}

\subsection{Characterization of Banana Pseudostem Biochars}

The FTIR spectra of banana pseudostem biochars are shown in Figure 1 . The peak at $3448 \mathrm{~cm}^{-1}$ was assigned to hydroxyl group, and the peaks at about 2928 and $2860 \mathrm{~cm}^{-1}$ were assigned to aliphatic $-\mathrm{CH}$ and $-\mathrm{CH}_{2}$ stretching vibrations, respectively [30]. The peaks at $1630 \mathrm{~cm}^{-1}$ resulted from both the $\mathrm{C}=\mathrm{O}$ stretching vibration and $\mathrm{C}=\mathrm{C}$ stretching vibration of aromatic ring. The peak at about $1433 \mathrm{~cm}^{-1}$ also corresponded to aromatic $\mathrm{C}=\mathrm{C}$ stretching vibration of aromatic ring [31]. Obviously, the peak at $1630 \mathrm{~cm}^{-1}$ reduced and the peak at $1433 \mathrm{~cm}^{-1}$ increased while increasing the pyrolysis temperature to 500 and $600{ }^{\circ} \mathrm{C}$, as decarbonylation and aromatization intensively took place at high temperature [32]. The peak at $1385 \mathrm{~cm}^{-1}$ was symmetrical stretching vibration of $\mathrm{COO}^{-}[33,34]$. The peak at $1317 \mathrm{~cm}^{-1}$ was assigned to aliphatic $\mathrm{CH}_{2}$ deformation vibration [31]. The peaks at $1117 \mathrm{~cm}^{-1}$ and $1067 \mathrm{~cm}^{-1}$ represented alkoxy $\mathrm{C}-\mathrm{O}$ and aromatic $\mathrm{C}-\mathrm{O}$ stretching vibrations, respectively. The shift of $\mathrm{C}-\mathrm{O}$ peaks also confirmed that aromatization took place as increasing pyrolysis temperature [35]. The peaks at $876 \mathrm{~cm}^{-1}$ and $781 \mathrm{~cm}^{-1}$ were assigned to Si-O-Si symmetric stretching vibrations [36].

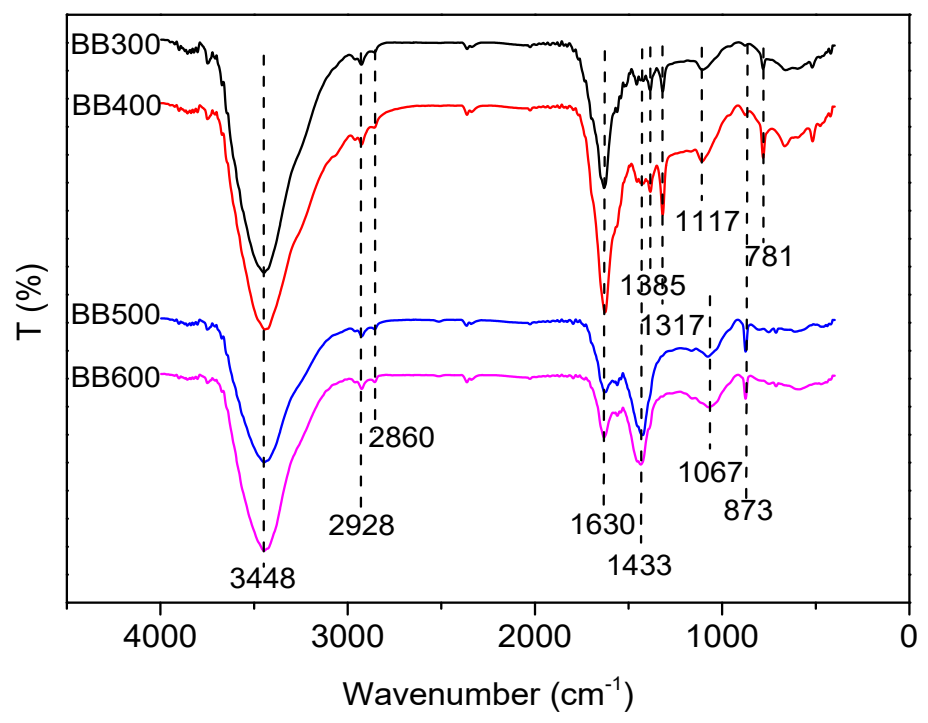

Figure 1. The Fourier-transform infrared (FTIR) spectra of banana pseudostem biochars.

The surface area, pore volume and average pore size of banana pseudostem biochars are given in Table 1. The biochars were of mesoporous structure [37], the average pore diameter (PD) and pore volume (PV) increased with pyrolysis temperature. The BET surface area (SA) slightly increased as 
pyrolysis temperature increased from 300 to $500{ }^{\circ} \mathrm{C}$, then decreased as reaching $600{ }^{\circ} \mathrm{C}$. This was probably because of formation of more mesopores caused by escape of volatile substances with increasing temperature and destruction of pore structures at high temperature [38]. The same correlation between surface area and pyrolysis temperature was also observed in previous biochar adsorption study [39].

Table 1. The surface area, pore volume and pore diameter of banana pseudostem biochars.

\begin{tabular}{ccccc}
\hline BC & BB300 & BB400 & BB500 & BB600 \\
\hline $\mathrm{SA}\left(\mathrm{m}^{2} / \mathrm{g}\right)$ & 4.98 & 6.62 & 11.27 & 8.53 \\
$\mathrm{PV}\left(\mathrm{cm}^{3} / \mathrm{g}\right)$ & 0.00959 & 0.01458 & 0.03932 & 0.04389 \\
$\mathrm{PD}(\mathrm{nm})$ & 10.39 & 11.85 & 15.60 & 19.45 \\
\hline
\end{tabular}

The $\mathrm{C}$ 1s XPS peaks of banana pseudostem biochars are shown in Figure 2, and the ratios of $\mathrm{C}-\mathrm{O}, \mathrm{C}=\mathrm{O}, \mathrm{COO}$ and $\mathrm{CO}_{3}{ }^{2-}$ bonds to the $\mathrm{C}-\mathrm{C}$ bonds based on peak area are presented in Table 2 . The total content of O-containing groups (TCOG) including $\mathrm{C}-\mathrm{O}, \mathrm{C}=\mathrm{O}, \mathrm{COO}$ and $\mathrm{CO}_{3}{ }^{2-}$, an important parameter affecting the adsorption capability of biochars [40], generally decreased as pyrolysis temperature increased from 300 to $600{ }^{\circ} \mathrm{C}$, as previously reported by $\mathrm{Li}$ [35]. Both $\mathrm{C}-\mathrm{O}$ and $\mathrm{C}=\mathrm{O}$ bonds sharply decreased, and $\mathrm{COO}$ and $\mathrm{CO}_{3}{ }^{2-}$ basically remained unchanged, as the pyrolysis temperature increased from 300 to $400{ }^{\circ} \mathrm{C}$. This might be due to the intense decomposition of cellulose and hemicellulose by breaking the $\mathrm{C}-\mathrm{O}$ and $\mathrm{C}=\mathrm{O}$ groups [41-43]. While the pyrolysis temperature increased to $500{ }^{\circ} \mathrm{C}$, the $\mathrm{C}=\mathrm{O}$ group sharply reduced with slight reduction of $\mathrm{CO}_{3}{ }^{2-}$, and the $\mathrm{COO}$ obviously increased, indicating $\mathrm{C}=\mathrm{O}$ and $\mathrm{CO}_{3}{ }^{2-}$ groups generated at low temperature were broken and $\mathrm{COO}$ groups were created at high temperature. With further increase of pyrolysis temperature to $600{ }^{\circ} \mathrm{C}$, there were not significant changes of $\mathrm{O}$-containing groups, as the degradation became relatively gradual when the temperature was up to $500{ }^{\circ} \mathrm{C}[26,32]$.
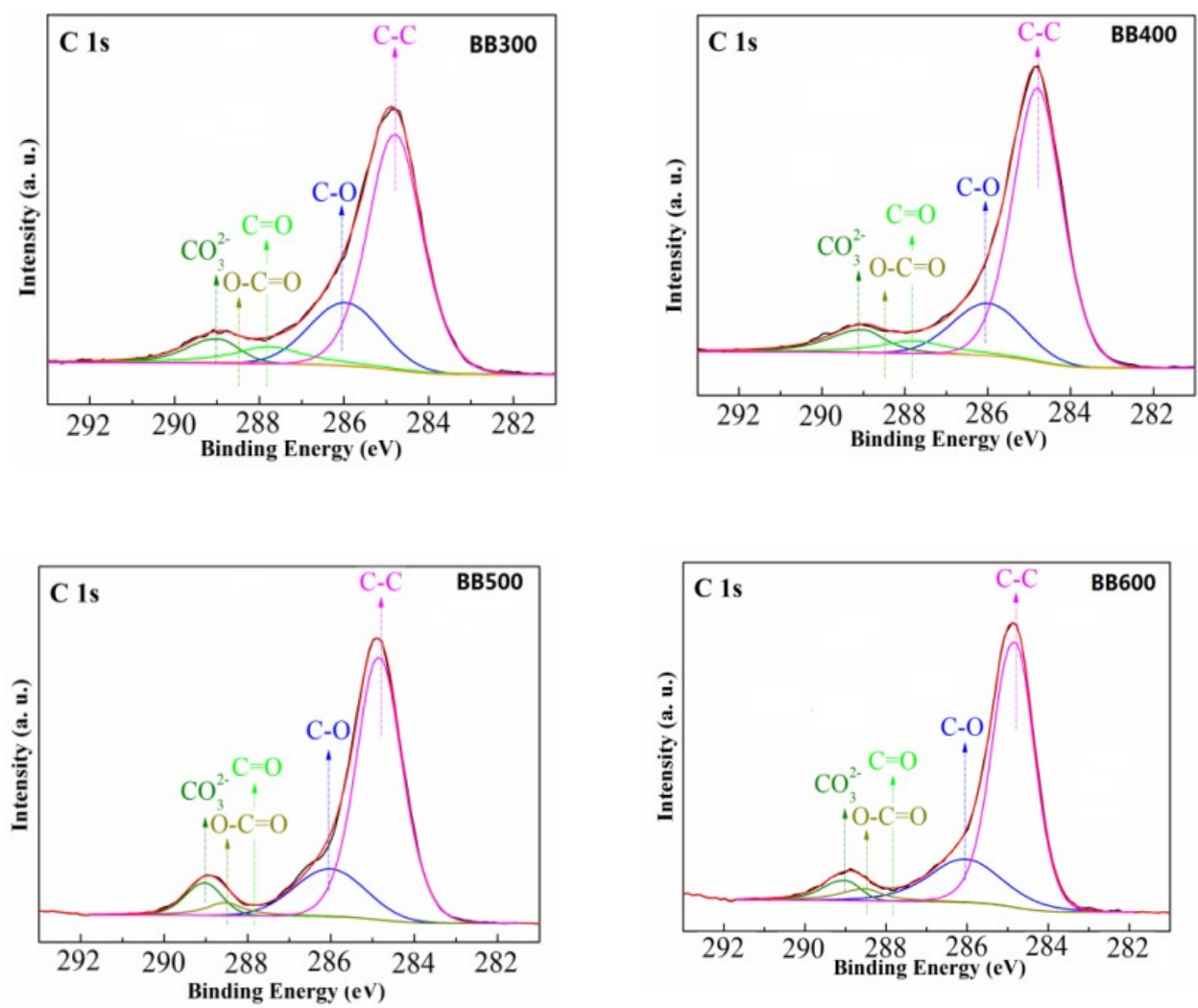

Figure 2. The XPS C 1s scans and peak fitting for banana pseudostem biochars. 
Table 2. The peak area ratios of $\mathrm{C}-\mathrm{O}, \mathrm{C}=\mathrm{O}, \mathrm{O}-\mathrm{C}=\mathrm{O}$ and $\mathrm{CO}_{3}{ }^{2-}$ bonds to the $\mathrm{C}-\mathrm{C}$ bonds of $\mathrm{C} 1 \mathrm{~s}$ XPS spectra of biochars.

\begin{tabular}{ccccccc}
\hline B.E. (eV) & Ass. & BB300 & BB400 & BB500 & BB600 & BB300+Cr \\
\hline C1 $(286.0)$ & $\mathrm{C}-\mathrm{O}(\%)$ & 34.14 & 26.25 & 26.94 & 29.56 & 43.52 \\
$\mathrm{C} 2(287.8)$ & $\mathrm{C}=\mathrm{O}(\%)$ & 12.62 & 8.50 & 0.11 & 0.13 & 0.52 \\
$\mathrm{C} 3(288.5)$ & $\mathrm{COO}(\%)$ & 0.74 & 0.85 & 5.20 & 5.73 & 8.81 \\
$\mathrm{C} 4(289.0)$ & $\mathrm{CO}_{3}{ }^{2-}(\%)$ & 10.47 & 10.39 & 9.85 & 7.19 & 5.35 \\
& TCOG & 57.97 & 45.99 & 42.10 & 42.61 & 58.20 \\
\hline
\end{tabular}

The surface morphologies of biochars are shown in Figure 3. The SEM image of BB300 revealed rod bundles with plicated surface and irregular small pieces, and BB400 also showed similar morphology. The SEM image of BB500 indicated that the rod bundles were partly destructed and became incompact. While the pyrolysis temperature was further raised to $600{ }^{\circ} \mathrm{C}$, the rod bundles were almost destructed to small pieces and irregular sheets with some small strips.
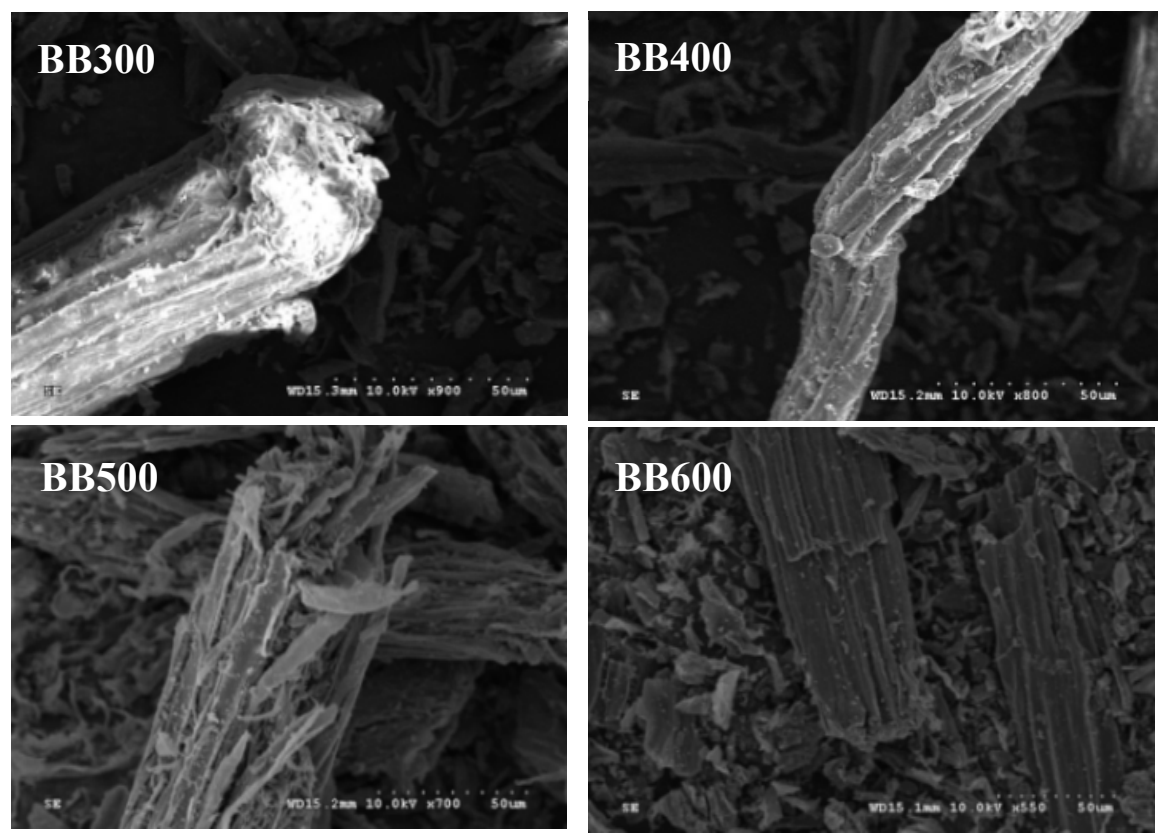

Figure 3. The SEM images of banana pseudostem biochars.

\subsection{Effects of $\mathrm{pH}$ and Pyrolysis Temperature}

The adsorption of $\mathrm{Cr}(\mathrm{VI})$ can be significantly influenced by $\mathrm{pH}$, due to its effects on (1) distribution of surface charge and ionic state of functional groups on the biochar surface $[23,44,45],(2)$ formation species and oxidizing ability of chromates [22,44,46]. As seen in Figure 4, the $\mathrm{Cr}(\mathrm{VI})$ adsorption efficiencies of all banana pseudostem biochars generally increased with decreasing initial $\mathrm{pH}$ of $\mathrm{Cr}(\mathrm{VI})$ solution, and the maximum adsorption capacity was obtained at $\mathrm{pH} 1$, which fully indicated that the biochars were more active under acidic conditions for $\mathrm{Cr}(\mathrm{VI})$ adsorption. For example, the adsorption of BB300 increased gradually from $6.94 \mathrm{mg} / \mathrm{g}$ to $18.36 \mathrm{mg} / \mathrm{g}$ with the decrease of $\mathrm{pH}$ from 5.0 to 3.0 , then increased sharply to $189.89 \mathrm{mg} / \mathrm{g}$ as the $\mathrm{pH}$ decreased to 1.0 . This was caused by the formation of massive positive charges on biochar surface and $\mathrm{HCr}_{2} \mathrm{O}^{7-}$ in the solution at lower $\mathrm{pH}$, which was favourable for the electron interaction between the biochars and chromate anions. Moreover, the oxidizing ability of chromate was significantly improved at low $\mathrm{pH}$, leading to remove more $\mathrm{Cr}(\mathrm{VI})$ by reduction $[22,23,42]$.

As a critical parameter influencing the physicochemical properties of biochars, pyrolysis temperature was found to play an important role in $\mathrm{Cr}(\mathrm{VI})$ adsorption capabilities of banana 
pseudostem biochars. The adsorption capability of the biochars remarkably increased with increase of pyrolysis temperature from 200 to $300^{\circ} \mathrm{C}$, then decreased with further increase of pyrolysis temperature. The best adsorption capacity of BB300 was up to $189.89 \mathrm{mg} / \mathrm{g}$ at pH 1 and $25^{\circ} \mathrm{C}$ (Figure 4). There were not significant changes in the surface area and microporosity of biochars altering pyrolysis temperature (Table 1). Whereas the content of O-containing groups which can be efficient factors for improving the redox, ion exchange and electron interaction abilities of biochars obviously reduced with the increase of pyrolysis temperature (Table 2). Thus, the decrease of adsorption capability with increase of temperature from 300 to $600{ }^{\circ} \mathrm{C}$ might be resulted from loss of surface O-containing groups. Similar results were also observed by Zhou et al. and Chen et al. [23,42]. As the adsorption capabilities of BB200 and BB600 were almost the same, the biochars prepared at different temperatures ranged from 300 to $600{ }^{\circ} \mathrm{C}$ were selected to study adsorption kinetics and isotherms.

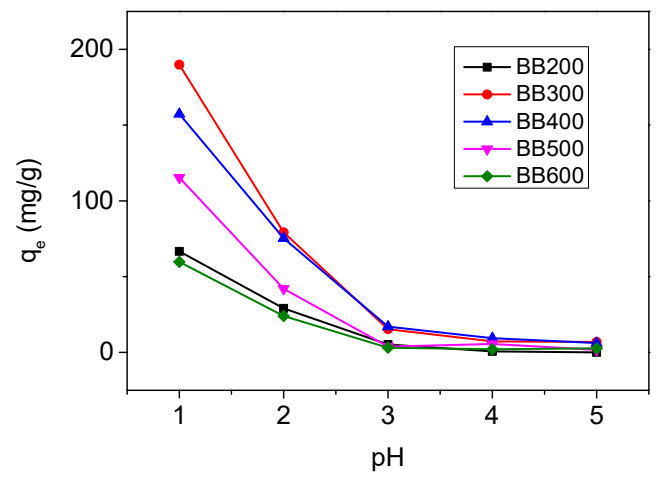

Figure 4. The effect of $\mathrm{pH}$ and pyrolysis temperature on adsorption capability (initial $\mathrm{Cr}(\mathrm{VI})$ concentration $=200 \mathrm{mg} / \mathrm{L}$; adsorbent dose $=1 \mathrm{~g} / \mathrm{L}$; temperature $=25^{\circ} \mathrm{C}$; contact time $=24 \mathrm{~h}$ ).

\subsection{Adsorption Kinetics}

The adsorption kinetics were studied at $\mathrm{pH} 2$ and described by the pseudo-first-order (Equation (2)) and pseudo-second-order (Equation (3)) models [47]:

$$
\begin{gathered}
\ln \left(\mathrm{q}_{\mathrm{e}}-\mathrm{q}_{\mathrm{t}}\right)=\ln \mathrm{q}_{\mathrm{e}}-\mathrm{k}_{1} \mathrm{t} \\
\frac{\mathrm{t}}{\mathrm{q}_{\mathrm{t}}}=\frac{1}{\mathrm{k}_{2} \mathrm{q}_{\mathrm{e}}^{2}}+\frac{1}{\mathrm{q}_{\mathrm{e}}} \mathrm{t}
\end{gathered}
$$

where $\mathrm{q}_{\mathrm{e}}$ and $\mathrm{q}_{\mathrm{t}}(\mathrm{mg} / \mathrm{g})$ are the equilibrium and instant adsorption capacities, respectively. $\mathrm{k}_{1}\left(\mathrm{~h}^{-1}\right)$ and $\mathrm{k}_{2}\left(\mathrm{~g} \cdot \mathrm{mg}^{-1} \cdot \mathrm{h}^{-1}\right)$ are the corresponding adsorption rate constants.

The adsorption kinetics of banana pseudostem biochars are presented in Figure 5. The adsorption of $\mathrm{Cr}(\mathrm{VI})$ gently increased with contact time and almost reached equilibrium after $48 \mathrm{~h}$. The calculated results of pseudo-first-order and pseudo-second-order rate equations are illustrated in Table 3. The correlation coefficients $\left(R^{2}\right)$ of the pseudo-second-order kinetic model were generally better than that of pseudo-first-order kinetic model. Meanwhile, the $\mathrm{q}_{\mathrm{e}}$ values calculated from pseudo-second-order equation were more consistent with the experimental results. These supported that the adsorption of $\mathrm{Cr}(\mathrm{VI})$ by banana pseudostem biochars was a chemiadsorption process. Adsorption kinetic studies of BB300 at different temperatures showed that $\mathrm{Cr}(\mathrm{VI})$ adsorption efficiences of the biochars increased greatly with temperature (Figure 6), suggesting the process was endothermic and high temperature was favorable for chromium removal, which might be due to more facile reduction of $\mathrm{Cr}(\mathrm{VI})$ by biochars at higher temperature [48,49]. The results also revealed that the adsorption kinetics were better described by pseudo-second-order model than pseudo-first-order model (Table 4). Additionally, comparing with the experimental results, the higher calculated $\mathrm{q}_{\mathrm{e}}$ results by pseudo-second-order model seemed more reasonable, as the adsorptions might not reach equilibrium within $48 \mathrm{~h}$. 

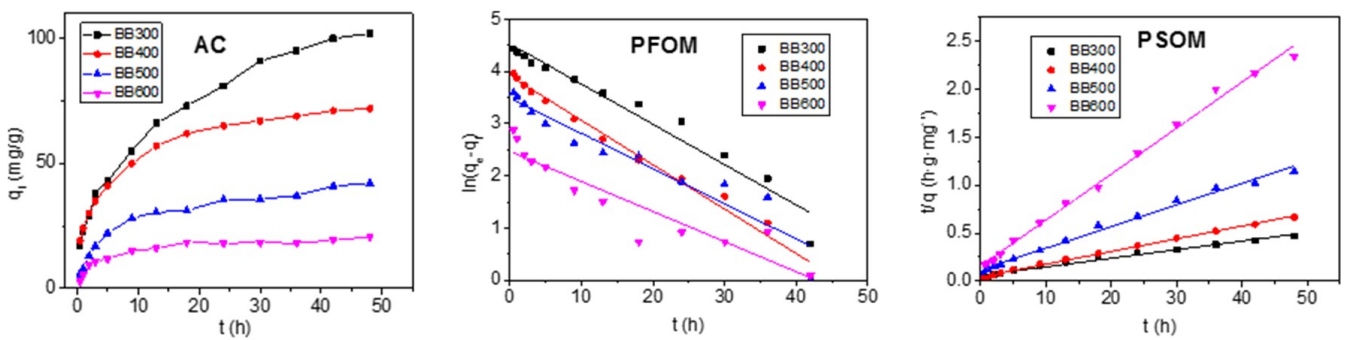

Figure 5. The adsorption kinetics of biochar for $\mathrm{Cr}(\mathrm{VI})$. $\mathrm{AC}$ is the adsorption curve of $\mathrm{Cr}(\mathrm{VI})$; $\mathrm{PFOM}$ is the pseudo-first-order model; PSOM is the pseudo-second-order model (initial $\mathrm{Cr}(\mathrm{VI})$ concentration = $200 \mathrm{mg} / \mathrm{L}$; adsorbent dose $=1 \mathrm{~g} / \mathrm{L} ; \mathrm{pH}=2$; temperature $=25^{\circ} \mathrm{C}$ ).

Table 3. The fitting results of $\mathrm{Cr}(\mathrm{VI})$ adsorption using pseudo-first-order and pseudo-second-order models.

\begin{tabular}{ccccc}
\hline & \multicolumn{4}{c}{ Pseudo-First-Order Model } \\
\cline { 2 - 5 } & $\mathbf{B B 3 0 0}$ & $\mathbf{B B 4 0 0}$ & $\mathbf{B B 5 0 0}$ & $\mathbf{B B 6 0 0}$ \\
\hline $\mathrm{q}_{\mathrm{e}, \exp }$ & 102.45 & 72.21 & 42.01 & 20.58 \\
$\mathrm{q}_{\mathrm{e}, \text { cal }}$ & 93.03 & 50.25 & 32.70 & 11.35 \\
$\mathrm{k}_{1}$ & $7.72 \times 10^{-2}$ & $8.51 \times 10^{-2}$ & $6.74 \times 10^{-2}$ & $5.63 \times 10^{-2}$ \\
$\mathrm{R}^{2}$ & 0.96073 & 0.98212 & 0.90456 & 0.86206 \\
\hline \multicolumn{5}{c}{ Pseudo-Second-Order Model } \\
\cline { 2 - 5 } & $\mathbf{B B 3 0 0}$ & $\mathbf{B B 4 0 0}$ & $\mathbf{B B 5 0 0}$ & $\mathbf{B B 6 0 0}$ \\
\hline $\mathrm{q}_{\mathrm{e}, \exp }$ & 102.45 & 72.21 & 42.01 & 20.58 \\
$\mathrm{q}_{\mathrm{e}, \text { cal }}$ & 111.35 & 75.20 & 44.40 & 20.88 \\
$\mathrm{k}_{2}$ & $1.35 \times 10^{-3}$ & $3.92 \times 10^{-3}$ & $4.29 \times 10^{-3}$ & $1.45 \times 10^{-2}$ \\
$\mathrm{R}^{2}$ & 0.98054 & 0.99660 & 0.99096 & 0.99493 \\
\hline
\end{tabular}
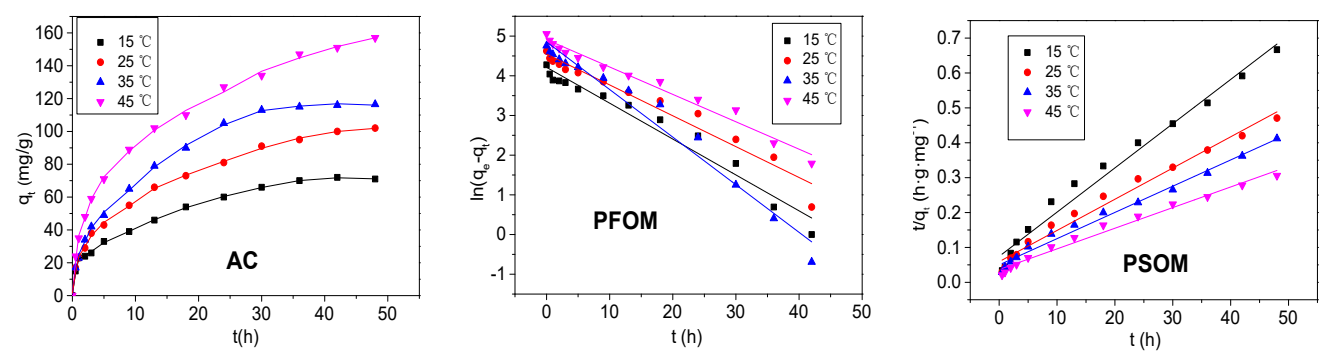

Figure 6. The adsorption kinetics of $\mathrm{BB} 300$ for $\mathrm{Cr}(\mathrm{VI})$ at different temperatures. $\mathrm{AC}$ is the adsorption curve of $\mathrm{Cr}(\mathrm{VI})$; PFOM is the pseudo-first-order model; PSOM is the pseudo-second-order model (initial $\mathrm{Cr}(\mathrm{VI})$ concentration $=200 \mathrm{mg} / \mathrm{L}$; adsorbent dose $=1 \mathrm{~g} / \mathrm{L} ; \mathrm{pH}=2$ ).

Table 4. The fitting results of $\mathrm{Cr}(\mathrm{VI})$ adsorption on BB300 at different temperatures using pseudo-firstorder and pseudo-second-order models.

\begin{tabular}{ccccc}
\hline & \multicolumn{4}{c}{ Pseudo-First-Order Model } \\
\cline { 2 - 5 } & $\mathbf{1 5}{ }^{\circ} \mathbf{C}$ & $\mathbf{2 5}{ }^{\circ} \mathbf{C}$ & $\mathbf{3 5}{ }^{\circ} \mathbf{C}$ & $\mathbf{4 5}{ }^{\circ} \mathbf{C}$ \\
\hline $\mathrm{q}_{\mathrm{e}, \exp }$ & 72.04 & 102.45 & 116.50 & 156.56 \\
$\mathrm{q}_{\mathrm{e}, \text { cal }}$ & 67.63 & 94.36 & 128.17 & 135.94 \\
$\mathrm{k}_{1}$ & $9.04 \times 10^{-2}$ & $7.78 \times 10^{-2}$ & $1.20 \times 10^{-1}$ & $6.90 \times 10^{-2}$ \\
$\mathrm{R}^{2}$ & 0.96007 & 0.95519 & 0.96748 & 0.97669 \\
\hline & \multicolumn{4}{c}{ Pseudo-Second-Order Model } \\
\cline { 2 - 5 } & $\mathbf{1 5}{ }^{\circ} \mathbf{C}$ & $\mathbf{2 5}{ }^{\circ} \mathbf{C}$ & $\mathbf{3 5}{ }^{\circ} \mathbf{C}$ & $\mathbf{4 5}{ }^{\circ} \mathbf{C}$ \\
\hline $\mathrm{q}_{\mathrm{e}, \text { exp }}$ & 72.04 & 102.45 & 116.50 & 156.56 \\
$\mathrm{q}_{\mathrm{e}, \mathrm{cal}}$ & 61.46 & 111.86 & 132.98 & 169.20 \\
$\mathrm{k}_{2}$ & $3.56 \times 10^{-3}$ & $1.35 \times 10^{-3}$ & $1.13 \times 10^{-3}$ & $9.50 \times 10^{-4}$ \\
$\mathrm{R}^{2}$ & 0.97909 & 0.98054 & 0.98770 & 0.98285 \\
\hline
\end{tabular}




\subsection{Adsorption Isotherms}

The Langmuir [50] and Freundlich models [51] were used to fit the isothermal adsorption data. These two models were described as Equations (4) and (5) respectively:

$$
\begin{gathered}
\mathrm{q}_{\mathrm{e}}=\frac{\mathrm{K}_{\mathrm{L}} \mathrm{q}_{\max } \mathrm{C}_{\mathrm{e}}}{1+\mathrm{K}_{\mathrm{L}} \mathrm{C}_{\mathrm{e}}},\left(\mathrm{R}_{\mathrm{L}}=\frac{1}{1+\mathrm{K}_{\mathrm{L}} \mathrm{C}_{0}}\right) \\
\mathrm{q}_{\mathrm{e}}=\mathrm{K}_{\mathrm{F}} \mathrm{C}_{\mathrm{e}}^{\mathrm{n}}
\end{gathered}
$$

where $C_{e}$ is the equilibrium concentrations of $\mathrm{Cr}(\mathrm{VI})$ in solutions $(\mathrm{mg} / \mathrm{L}) ; \mathrm{q}_{\mathrm{e}}$ and $\mathrm{q}_{\mathrm{max}}(\mathrm{mg} / \mathrm{g})$ are the equilibrium and maximum adsorption capacities of $\mathrm{Cr}(\mathrm{VI})$, respectively; The $\mathrm{R}_{\mathrm{L}}$ parameter is the dimensionless adsorption factor; $\mathrm{C}_{0}(\mathrm{mg} / \mathrm{L})$ is the initial concentration of $\mathrm{Cr}(\mathrm{VI})$ in the solution; $\mathrm{K}_{\mathrm{L}}(\mathrm{L} / \mathrm{mg})$ is the Langmuir constant related to binding energy. $\mathrm{K}_{\mathrm{F}}\left((\mathrm{mg} / \mathrm{g})(\mathrm{mg} / \mathrm{L})^{-\mathrm{n}}\right)$ is the Freundlich constant related to adsorption capacity and $\mathrm{n}$ is an indicator of the adsorption intensity.

Batch adsorption isotherms are shown as Figure 7. The equilibrium adsorption capacities of all biochars generally increased with concentration of $\mathrm{Cr}(\mathrm{VI})$ and reached maximum, the maximum adsorption capacities of BB300, BB400, BB500 and BB600 were $125.44 \mathrm{mg} / \mathrm{g}, 80.33 \mathrm{mg} / \mathrm{g}, 43.47 \mathrm{mg} / \mathrm{g}$ and $21.53 \mathrm{mg} / \mathrm{g}$ respectively. The adsorption isotherms was better fitted by Langmuir model than Freundlich model (Table 5), indicating monolayer adsorption onto homogeneous surface with limited active sites was a dominating process for $\mathrm{Cr}(\mathrm{VI})$ removal by banana pseudostem biochars $[52,53]$. The average value of adsorption factor $\left(R_{L}\right)$ of Langmuir isotherm was less than 1 , suggesting that the removal of $\mathrm{Cr}(\mathrm{VI})$ by the biochars was a highly efficient process.
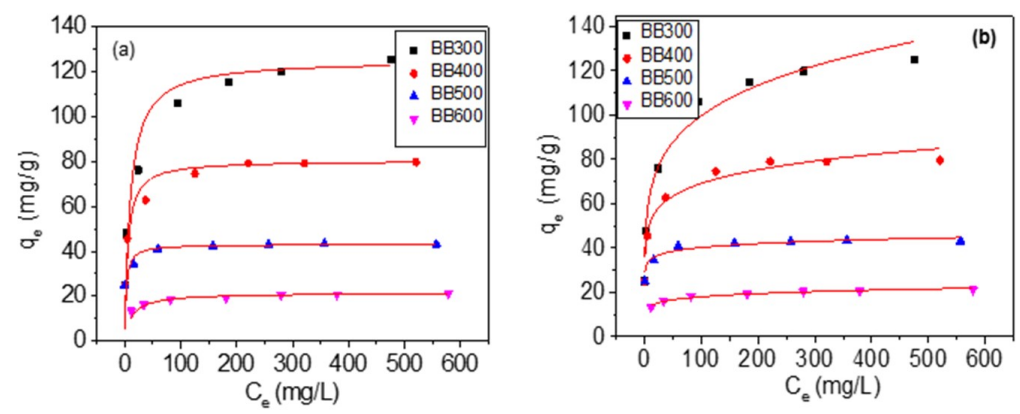

Figure 7. The adsorption isotherms of biochars for $\mathrm{Cr}(\mathrm{VI})$. (a) is the Langmuir model; (b) is the Freundlich model (initial $\mathrm{Cr}(\mathrm{VI})$ concentration $=25-600 \mathrm{mg} / \mathrm{L}$; adsorbent dose $=1 \mathrm{~g} / \mathrm{L} ; \mathrm{pH}=2$; contact time $=48 \mathrm{~h}$ ).

Table 5. The parameters of Langmuir and Freundlich isotherms of $\mathrm{Cr}(\mathrm{VI})$ adsorption.

\begin{tabular}{ccccc}
\hline & \multicolumn{4}{c}{ LM } \\
\cline { 2 - 5 } & BB300 & BB400 & BB500 & BB600 \\
\hline $\mathrm{q}_{\max }(\mathrm{mg} / \mathrm{g})$ & 125.44 & 80.33 & 43.47 & 21.53 \\
$\mathrm{~K}_{\mathrm{L}}(\mathrm{L} / \mathrm{mg})$ & 0.1024 & 0.1910 & 0.3929 & 0.0796 \\
$\mathrm{R}^{2}$ & 0.9977 & 0.9996 & 0.9999 & 0.9997 \\
\hline & \multicolumn{4}{c}{ FM } \\
\cline { 2 - 5 } & $\mathbf{B B 3 0 0}$ & $\mathbf{B B 4 0 0}$ & $\mathbf{B B 5 0 0}$ & $\mathbf{B B 6 0 0}$ \\
\hline $\mathrm{KF}$ & 42.64 & 39.07 & 30.25 & 10.67 \\
$(\mathrm{mg} / \mathrm{g}) \cdot(\mathrm{mg} / \mathrm{L})^{-\mathrm{n}}$ & 0.185 & 0.124 & 0.062 & 0.115 \\
$\mathrm{n}$ & 0.9813 & 0.9609 & 0.8030 & 0.9554 \\
$\mathrm{R}^{2}$ & \multicolumn{4}{c}{}
\end{tabular}

\subsection{Adsorption Mechanism}

The XPS and FTIR spectrometers were also performed after adsorption for exploring the $\mathrm{Cr}(\mathrm{VI})$ adsorption mechanism, as shown in Figures 8 and 9 respectively. The XPS results of BB300 after 
adsorption revealed that $\mathrm{Cr}(\mathrm{III})$ was primarily immobilized on the surface of BB300 with a small amount of $\mathrm{Cr}(\mathrm{VI})(\mathrm{Cr}(\mathrm{III}) / \mathrm{Cr}(\mathrm{VI})=97.51 / 2.49)$. The content of O-containing groups on the surface slightly increased and both $\mathrm{C}-\mathrm{O}$ and $\mathrm{COO}$ obviously increased (Table 2). In contrast, the content of $\mathrm{C}=\mathrm{O}$ and $\mathrm{CO}_{3}{ }^{2-}$ sharply reduced. These results indicated that reduction of $\mathrm{Cr}(\mathrm{VI})$ to $\mathrm{Cr}$ (III) [54-56] and adsorption of both $\mathrm{Cr}(\mathrm{III})$ and $\mathrm{Cr}(\mathrm{VI})$ onto the biochar surface were involved during the process. Additionally, the FTIR showed that the COO peak at $1686 \mathrm{~cm}^{-1}$, aromatic $C=C$ peak at $1429 \mathrm{~cm}^{-1}$ and C-O peak at $1109 \mathrm{~cm}^{-1}$ obviously increased for BB300 and BB400 after adsorption, implying that the biochars were oxidized by $\mathrm{Cr}(\mathrm{VI})$ and $\mathrm{COO}, \mathrm{C}-\mathrm{O}$ and aromatic ring were formed. Hence, the reduction of $\mathrm{Cr}(\mathrm{VI})$ by BB300 and BB400 during the adsorption was caused by oxidation and aromatization of the biochars. Differently, the aromatic $C=C$ peak at $1421 \mathrm{~cm}^{-1}$ diminished and $C=O$ peak at $1620 \mathrm{~cm}^{-1}$ increased for BB500 and BB600 after adsorption, indicating the reduction of $\mathrm{Cr}(\mathrm{VI})$ by BB500 and BB600 resulted from oxidation and dearomatization of the biochars. Moreover, adsorption kinetics were described well by pseudo-second-order model, suggesting the removal of $\mathrm{Cr}(\mathrm{VI})$ by the biochars was a chemical process. As a result, the decrease of adsorption capability of banana pesudostem biochar with increasing pyrolysis temperature was explained by the lost of surface $\mathrm{O}$-containing groups which played an important role in reduction of $\mathrm{Cr}(\mathrm{VI})$. In general, the adsorption of $\mathrm{Cr}(\mathrm{VI})$ was mainly attributed to reduction of $\mathrm{Cr}(\mathrm{VI})$ to $\mathrm{Cr}(\mathrm{III})$ followed by complexation and ion exchange rather than electron interaction with biochar, as the biochar surface was probably positive at $\mathrm{pH} 2$, hindering the electron interaction of $\mathrm{Cr}(\mathrm{III})$ cation with biochar. The precipitation of $\mathrm{Cr}(\mathrm{OH})_{3}$ on the surface of biochar also could be ruled out, as the predominant species of trivalent chromium was $\mathrm{Cr}$ (III) cation at low $\mathrm{pH}$ [57].
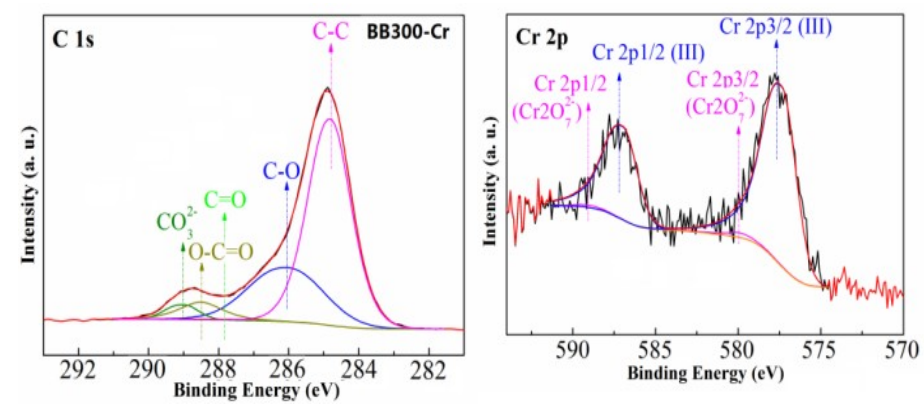

Figure 8. The XPS C 1s and Cr 2p scans and peaks fitting for BB300 after adsorption.
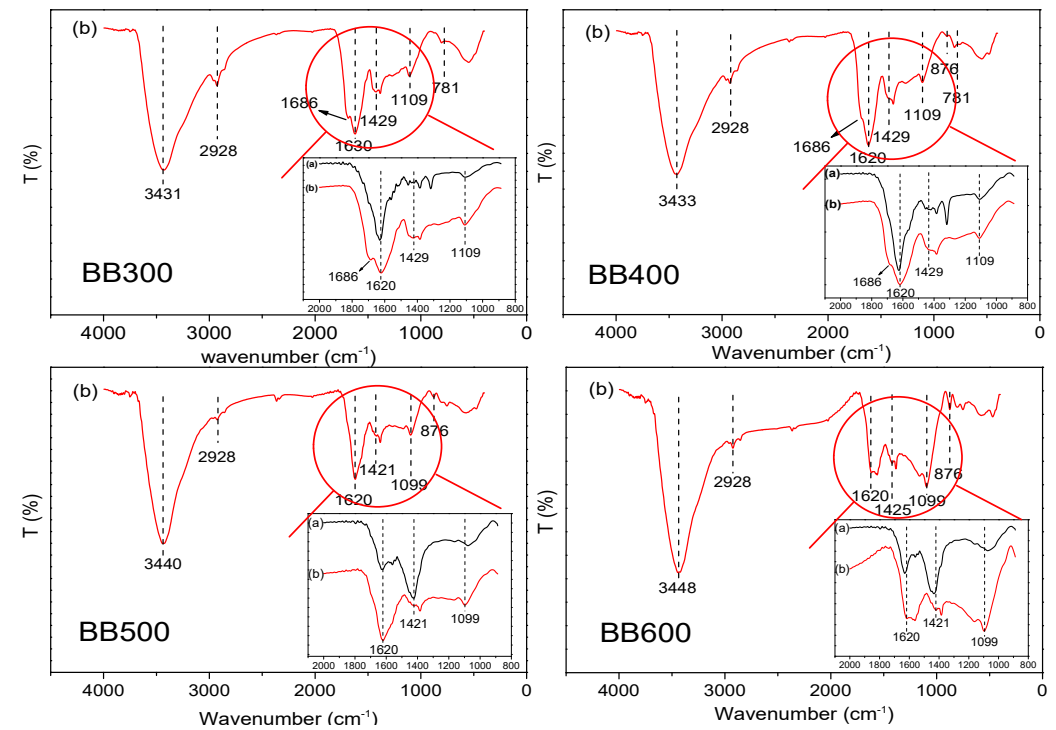

Figure 9. The FTIR spectra of biochars before and after adsorption of $\mathrm{Cr}(\mathrm{VI})$. Spectra (a) were before adsorption; Spectra (b) were after adsorption. 


\section{Conclusions}

The $\mathrm{Cr}(\mathrm{VI})$ adsorption capabilities of banana pseudostem biochar were highly affected by pyrolysis temperature. Low $\mathrm{pH}$ and high adsorption temperature were favourable for adsorption of $\mathrm{Cr}(\mathrm{VI})$. The biochar prepared at $300{ }^{\circ} \mathrm{C}$ exhibited best adsorption capability with $125.44 \mathrm{mg} / \mathrm{g}$ maximum adsorption capacity at $\mathrm{pH} 2$ and $25^{\circ} \mathrm{C}$. The high adsorption capability of the biochar might be attributed to high content of oxygen-containing functional groups on surface. The $\mathrm{Cr}(\mathrm{VI})$ adsorption by BB300 and BB400 resulted from their oxidation and aromatization with ion exchange and complexation, whereas the $\mathrm{Cr}(\mathrm{VI})$ adsorption by BB500 and BB600 was ascribed to their oxidation and dearomatization followed by ion exchange and complexation. As the feedstock is large-scale available and highly renewable biowaste, banana pseudostem biochar is a low-cost adsorbent and expected to have a practical application for remediation of chromium-polluted water in the future.

Author Contributions: Conceptualization, J.L. and Y.Z.; Methodology, J.L.; Software, S.X. and W.Y.; Validation, S.X. and S.L.; Formal Analysis, J.L. and Y.Z.; Investigation, S.X., W.Y. and S.L.; Resources, C.X.; Data Curation, S.X.; Writing-Original Draft Preparation, S.X.; Writing-Review \& Editing, J.L.; Visualization, J.L.; Supervision, J.L. and Y.Z.; Project Administration, C.X.; Funding Acquisition, Y.Z."

Funding: This research was funded by the key Scientific Research Project Funding of Hainan Province [ZDYF2017005], the National Natural Science Foundation of China [21801053] and the Innovation Project of Science and Technology Association of Hainan Province for Distinguished Young Scholar [HAST201625]; and the APC was funded by the key Scientific Research Project Funding of Hainan Province [ZDYF2017005].

Conflicts of Interest: The authors declare no conflicts of interest.

\section{References}

1. Bayazit, Ş.S.; Kerkez, Ö. Hexavalent chromium adsorption on superparamagnetic multi-wall carbon nanotubes and activated carbon composites. Chem. Eng. Res. Des. 2014, 92, 2725-2733. [CrossRef]

2. Pradhan, D.; Sukla, L.B.; Sawyer, M.; Rahman, P.K.S.M. Recent bioreduction of hexavalent chromium in wastewater treatment: A review. J. Ind. Eng. Chem. 2017, 55, 1-20. [CrossRef]

3. Costa, M.; Klein, C.B. Toxicity and carcinogenicity of chromium compounds in humans. Crit. Rev. Toxicol. 2006, 36, 155-163. [CrossRef] [PubMed]

4. Li, Q.; Liu, H.; Alattar, M.; Jiang, S.; Han, J.; Ma, Y.; Jiang, C. The preferential accumulation of heavy metals in different tissues following frequent respiratory exposure to PM2.5 in rats. Sci. Rep. 2015, 5, 16936-16944. [CrossRef] [PubMed]

5. Niu, Y.; Jiao, W.; Yu, H.; Niu, Y.; Pang, Y.; Xu, X.; Guo, X. Spatial evaluation of heavy metals concentrations in the surface sediment of Taihu Lake. Int. J. Environ. Res. Public Health 2015, 12, 15028-15039. [CrossRef] [PubMed]

6. Kotaś, J.; Stasicka, Z. Chromium occurrence in the environment and methods of its speciation. Environ. Pollut. 2000, 107, 263-283. [CrossRef]

7. Bagchi, D.; Stohs, S.J.; Downs, B.W.; Bagchi, M.; Preuss, H.G. Cytotoxicity and oxidative mechanisms of different forms of chromium. Toxicology 2002, 180, 5-22. [PubMed]

8. Tu, W.; Li, K.; Shu, X.; Yu, W.W. Reduction of hexavalent chromium with colloidal and supported palladium nanocatalysts. J. Nanopart. Res. 2013, 15, 1593-1602.

9. Kongsricharoem, N.; Polprasert, C. Chromium removal by a bipolar electro-chemical precipitation process. Water Sci. Technol. 1996, 34, 109-116.

10. Song, Z.; Williams, C.J.; Edyvean, R.G.J. Sedimentation of tannery wastewater. Water Res. 2000, 34, $2171-2176$. [CrossRef]

11. Wang, G.; Chang, Q.; Han, X.; Zhang, M. Removal of Cr(VI) from aqueous solution by flocculant with the capacity of reduction and chelation. J. Hazard. Mater. 2013, 248-249, 115-121. [CrossRef] [PubMed]

12. Karthikeyan, T.; Rajgopal, S.; Miranda, L.R. Chromium(VI) adsorption from aqueous solution by Hevea brasilinesis sawdust activated carbon. J. Hazard. Mater. 2005, 124, 192-199. [CrossRef] [PubMed]

13. Ghosh, G.; Bhattacharya, P.K. Hexavalent chromium ion removal through micellar enhanced ultrafiltration. Chem. Eng. J. 2006, 119, 45-53. [CrossRef] 
14. Rengaraj, S.; Yeon, K.-H.; Moon, S.-H. Removal of chromium from water and wastewater by ion exchange resins. J. Hazard. Mater. 2001, B87, 273-287. [CrossRef]

15. Achouri, O.; Panico, A.; Bencheikh-Lehocine, M.; Derbal, K.; Pirozzi, F. Effect of chemical coagulation pretreatment on anaerobic digestion of tannery wastewater. J. Environ. Eng. 2017, 143, 04017039. [CrossRef]

16. Mohan, D.; Singh, K.P.; Singh, V.K. Trivalent chromium removal from wastewater using low cost activated carbon derived from agricultural waste material and activated carbon fabric cloth. J. Hazard. Mater. 2006, 135, 280-295. [CrossRef] [PubMed]

17. Yan, L.; Kong, L.; Qu, Z.; Li, L.; Shen, G. Magnetic biochar decorated with ZnS nanocrytals for Pb (II) removal. ACS Sustain. Chem. Eng. 2014, 3, 125-132. [CrossRef]

18. Ahmad, M.; Rajapaksha, A.U.; Lim, J.E.; Zhang, M.; Bolan, N.; Mohan, D.; Vithanage, M.; Lee, S.S.; Ok, Y.S. Biochar as a sorbent for contaminant management in soil and water: A review. Chemosphere 2014, 99, 19-33. [CrossRef] [PubMed]

19. Cheng, B.H.; Zeng, R.J.; Jiang, H. Recent developments of post-modification of biochar for electrochemical energy storage. Bioresour. Technol. 2017, 246, 224-233. [CrossRef] [PubMed]

20. Oliveira, F.R.; Patel, A.K.; Jaisi, D.P.; Adhikari, S.; Lu, H.; Khanal, S.K. Environmental application of biochar: Current status and perspectives. Bioresour. Technol. 2017, 246, 110-122. [CrossRef] [PubMed]

21. Mohan, D.; Sarswat, A.; Ok, Y.S.; Pittman, C.U., Jr. Organic and inorganic contaminants removal from water with biochar, a renewable, low cost and sustainable adsorbent-A critical review. Bioresour. Technol. 2014, 160, 191-202. [CrossRef] [PubMed]

22. Mohan, D.; Rajput, S.; Singh, V.K.; Steele, P.H.; Pittman, C.U., Jr. Modeling and evaluation of chromium remediation from water using low cost bio-char, a green adsorbent. J. Hazard. Mater. 2011, 188, 319-333. [PubMed]

23. Zhou, L.; Liu, Y.; Liu, S.; Yin, Y.; Zeng, G.; Tan, X.; Hu, X.; Hu, X.; Jiang, L.; Ding, Y.; et al. Investigation of the adsorption-reduction mechanisms of hexavalent chromium by ramie biochars of different pyrolytic temperatures. Bioresour. Technol. 2016, 218, 351-359. [CrossRef] [PubMed]

24. Duan, S.; Ma, W.; Pan, Y.; Meng, F.; Yu, S.; Wu, L. Synthesis of magnetic biochar from iron sludge for the enhancement of Cr (VI) removal from solution. J. Taiwan Inst. Chem. Eng. 2017, 80, 835-841. [CrossRef]

25. Dong, X.; Ma, L.Q.; Li, Y. Characteristics and mechanisms of hexavalent chromium removal by biochar from sugar beet tailing. J. Hazard. Mater. 2011, 190, 909-915. [CrossRef] [PubMed]

26. Shen, Y.S.; Wang, S.L.; Tzou, Y.M.; Yan, Y.Y.; Kuan, W.H. Removal of hexavalent Cr by coconut coir and derived chars-The effect of surface functionality. Bioresour. Technol. 2012, 104, 165-172. [CrossRef] [PubMed]

27. Zhang, X.; Zhang, X.; Chen, Z. Biosorption of $\mathrm{Cr}(\mathrm{VI})$ from aqueous solution by biochar derived from the leaf of Leersia hexandra Swartz. Environ. Earth Sci. 2017, 76, 67-74. [CrossRef]

28. Shah, M.P.; Reddy, G.V.; Banerjee, R.; Ravindra Babu, P.; Kothari, I.L. Microbial degradation of banana waste under solid state bioprocessing using two lignocellulolytic fungi (Phylosticta spp. MPS-001 and Aspergillus spp. MPS-002). Process. Biochem. 2005, 40, 445-451. [CrossRef]

29. Jayaprabha, J.S.; Brahmakumar, M.; Manilal, V.B. Banana pseudostem characterization and its fiber property evaluation on physical and bioextraction. J. Nat. Fibers 2011, 8, 149-160. [CrossRef]

30. Li, D.-C.; Ding, J.-W.; Qian, T.-T.; Zhang, S.; Jiang, H. Preparation of high adsorption performance and stable biochar granules by $\mathrm{FeCl}_{3}$-catalyzed fast pyrolysis. RSC Adv. 2016, 6, 12226-12234. [CrossRef]

31. Özçimen, D.; Ersoy-Meriçboyu, A. Characterization of biochar and bio-oil samples obtained from carbonization of various biomass materials. Renew. Energy 2010, 35, 1319-1324. [CrossRef]

32. Chen, B.; Chen, Z. Sorption of naphthalene and 1-naphthol by biochars of orange peels with different pyrolytic temperatures. Chemosphere 2009, 76, 127-133. [CrossRef] [PubMed]

33. Lian, F.; Xing, B.; Zhu, L. Comparative study on composition, structure, and adsorption behavior of activated carbons derived from different synthetic waste polymers. J. Colloid Interface Sci. 2011, 360, 725-730. [CrossRef] [PubMed]

34. Song, Z.; Lian, F.; Yu, Z.; Zhu, L.; Xing, B.; Qiu, W. Synthesis and characterization of a novel $\mathrm{MnO}_{\mathrm{x}}$-loaded biochar and its adsorption properties for $\mathrm{Cu}^{2+}$ in aqueous solution. Chem. Eng. J. 2014, 242, 36-42.

35. Li, G.; Zhu, W.; Zhang, C.; Zhang, S.; Liu, L.; Zhu, L.; Zhao, W. Effect of a magnetic field on the adsorptive removal of methylene blue onto wheat straw biochar. Bioresour. Technol. 2016, 206, 16-22. [CrossRef] [PubMed] 
36. Qian, L.; Zhang, W.; Yan, J.; Han, L.; Chen, Y.; Ouyang, D.; Chen, M. Nanoscale zero-valent iron supported by biochars produced at different temperatures: Synthesis mechanism and effect on $\mathrm{Cr}(\mathrm{VI})$ removal. Environ. Pollut. 2017, 223, 153-160. [PubMed]

37. Sun, L.; Wan, S.; Luo, W. Biochars prepared from anaerobic digestion residue, palm bark, and eucalyptus for adsorption of cationic methylene blue dye: Characterization, equilibrium, and kinetic studies. Bioresour. Technol. 2013, 140, 406-413. [PubMed]

38. Tan, X.; Liu, Y.; Zeng, G.; Wang, X.; Hu, X.; Gu, Y.; Yang, Z. Application of biochar for the removal of pollutants from aqueous solutions. Chemosphere 2015, 125, 70-85. [PubMed]

39. Zeng, Z.-W.; Tian, S.-R.; Liu, Y.-G.; Tan, X.-F.; Zeng, G.-M.; Jiang, L.-H.; Yin, Z.-H.; Liu, N.; Liu, S.-B.; Li, J. Comparative study of rice husk biochars for aqueous antibiotics removal. J. Chem. Technol. Biotechnol. 2017, 93, 1075-1084. [CrossRef]

40. Chen, B.; Zhou, D.; Zhu, L. Transitional adsorption and partition on nonpolar and polar aromatic contaminants by biochars of pine needles with different pyrolytic temperatures. Environ. Sci. Technol. 2008, 42, 5137-5143. [CrossRef] [PubMed]

41. Abdullah, N.; Sulaiman, F.; Miskam, M.A.; Taib, R.M. Characterization of banana (Musa spp.) pseudo-stem and fruit-bunch-Stem as a potential renewable energy resource. Int. J. Biol. Veter. Agric. Food Eng. 2014, 8, 712-716.

42. Chen, D.; Yu, X.; Song, C.; Pang, X.; Huang, J.; Li, Y. Effect of pyrolysis temperature on the chemical oxidation stability of bamboo biochar. Bioresour. Technol. 2016, 218, 1303-1306. [CrossRef] [PubMed]

43. Zhou, W.; Li, W.; Li, J.; Zhang, Y. Characterization of cellulose from banana pseudo-stem by polyhydric alcohols liquefaction. Renew. Energy Resour. 2016, 34, 285-291.

44. Chen, T.; Zhou, Z.; Xu, S.; Wang, H.; Lu, W. Adsorption behavior comparison of trivalent and hexavalent chromium on biochar derived from municipal sludge. Bioresour. Technol. 2015, 190, 388-394. [CrossRef] [PubMed]

45. Tytlak, A.; Oleszczuk, P.; Dobrowolski, R. Sorption and desorption of $\mathrm{Cr}(\mathrm{VI})$ ions from water by biochars in different environmental conditions. Environ. Sci. Pollut. Res. Int. 2015, 22, 5985-5994. [CrossRef] [PubMed]

46. Di Natale, F.; Erto, A.; Lancia, A.; Musmarra, D. Equilibrium and dynamic study on hexavalent chromium adsorption onto activated carbon. J. Hazard. Mater. 2015, 281, 47-55. [CrossRef] [PubMed]

47. Nityanandi, D.; Subbhuraam, C.V. Kinetics and thermodynamic of adsorption of chromium(VI) from aqueous solution using puresorbe. J. Hazard. Mater. 2009, 170, 876-882. [CrossRef] [PubMed]

48. Patel, S.; Mishra, B.K. Oxidation of alcohol by lipopathic Cr(VI): A mechanistic study. J. Org. Chem. 2006, 71, 6759-6766. [CrossRef] [PubMed]

49. Xu, F.; Ma, T.; Zhou, L.; Hu, Z.; Shi, L. Chromium isotopic fractionation during Cr(VI) reduction by Bacillus sp. under aerobic conditions. Chemosphere 2015, 130, 46-51. [CrossRef] [PubMed]

50. Langmuir, I. The adsorption of gases on plane surfaces of glass, mica and platinum. J. Am. Chem. Soc. 1918, 40, 1361-1403. [CrossRef]

51. Albadarin, A.B.; Mo, J.; Glocheux, Y.; Allen, S.; Walker, G.; Mangwandi, C. Preliminary investigation of mixed adsorbents for the removal of copper and methylene blue from aqueous solutions. Chem. Eng. J. 2014, 255, 525-534. [CrossRef]

52. Langmuir, I. The constitution and fundamental properties of solids and liquids. J. Am. Chem. Soc. 1916, 38, 2221-2295. [CrossRef]

53. Özcan, A.S.; Erdem, B.; Özcan, A. Adsorption of acid blue 193 from aqueous solutions onto BTMA-bentonite. Colloids Surf. Physicochem. Eng. Asp. 2005, 266, 73-81. [CrossRef]

54. Wiberg, K.B.; Schaferlb, H. Chromic acid oxidation of isopropyl alcohol. preoxidation equilibria. J. Am. Chem. Soc. 1969, 91, 927-932. [CrossRef]

55. Hiran, B.L.; Chaplot, S.L.; Joshi, V.; Chaturvedi, G. Kinetics of the effect of some bidentate amino acid ligands in the oxidation of lactic acid by chromium(VI). J. Am. Chem. Soc. 2002, 43, 657-661.

56. Rorek, J.; Radkowsky, A.E. Mechanism of the chromic acid oxidation of cyclobutanol. J. Am. Chem. Soc. 1973, 95, 7123-7132.

57. Fahim, N.F.; Barsoum, B.N.; Eid, A.E.; Khalil, M.S. Removal of chromium (III) from tannery wastewater using activated carbon from sugar industrial waste. J. Hazard. Mater. 2006, 136, 303-309. [CrossRef] [PubMed]

(C) 2018 by the authors. Licensee MDPI, Basel, Switzerland. This article is an open access article distributed under the terms and conditions of the Creative Commons Attribution (CC BY) license (http:/ / creativecommons.org/licenses/by/4.0/). 